\title{
Multi-person Decision Model for Unfinished Construction Project
}

\author{
Christiono Utomo ${ }^{1}$
}

\begin{abstract}
This paper discusses a proposed model of multi-person decision on prioritizing selection with regard to continuing or terminating unfinished construction projects. This involved multiple steps including determining criteria and sub criteria, selecting and weighting of alternatives, optimizing, and analyzing coalition formation and agreement option. Criteria and sub criteria that were obtained from perspectives of $\mathbf{1 2 0}$ project managers are the first basis to construct decision hierarchy. The model is implemented in one of the biggest private construction projects in Indonesia. The implementation was based on the Analytic Hierarchy Process for multi criteria decision involving coalition and agreement options in a multi-person decision. Goal Programming was used to optimize based on cost constrains. The results demonstrate a process of multiperson decision to select priorities of each alternative to each decision and concluded that some of the projects were continued, postponed or terminated. The new direction of research presented in this paper presents some interesting challenges to those involved in modeling computer-based multi-person decision support utilizing both Multi Agent System and Multi Criteria Decision Making.
\end{abstract}

Keywords -MCDM, multi-person decision, unfinished construction project, coalition

\section{INTRODUCTION}

$\mathrm{D}$ ecision for unfinished construction project is very complicated since there are many parties involved and time is also critical. Where a number of decision makers are involved in choosing a single alternative from a set of possible alternatives, there are different concerns caused by differing preferences, experiences, and background. Therefore, a multi-person decision is required to evaluate and rank the solution alternatives before engaging into negotiation among decision makers [1]. As the process involves multi disciplines and teamwork, negotiation plays an important role for multiperson decision to select unfinished construction project that will be continued, postponed, or terminated.

The research objective presented in this paper is to propose a model of multi-person decision on prioritizing selection with regard to continuing or terminating unfinished construction projects. The objective is attained by combination model of group decision model and coalition formation model for negotiation. This model provides a set of analysis on cooperative game theory to get the best fit decision for agreement option among decision makers.

Negotiation is an interactive communication on a multi-person decision to facilitate a distributed search process. It can be used to effectively coordinate the behavior among decision makers [2] and [3]. Kraus proposed two approaches for the development of

${ }^{1}$ Christiono Utomo is with Department of Civil Engineering, FTSP, Institut Teknologi Sepuluh Nopember, Surabaya, 60111, Indonesia. Email: christiono@ce.its.ac.id. theorems relating to the negotiation process [4]. The first is informal theory, which attempts to identify possible strategies for a negotiator and to assist a negotiator in achieving optimal results. The other approach is the formal theory of bargaining, originating with the work of John Nash, who attempted to construct formal models of negotiation environments. Therefore, negotiation support is useful for negotiation process. Game theory based negotiation and multi-attribute utilizing theory based negotiation [5] are theoretical approaches for negotiation support. Morge and Beaune [6] wrote that a negotiation support system provides three kinds of functionality. Firstly, it facilitates the exchange of information among users. Secondly, it provides decision modeling or groupdecision techniques to reduce the noise and uncertainty that occur in the process. Finally, it provides negotiation support. The field of Artificial Intelligence in particular multi-agent methods can be useful for negotiation support on a multi-person decision [7].

Many literatures on unfinished construction project decision describe various methods. In general, they are divided in to four sub-categories; comparative approaches, scoring models, benefit contribution or economic models and optimization methods [8, 9, 10, 11]. However, none of them can be applied in multi-person decision and negotiation. There is also very little research related to the applications of multi-person decision and negotiation support to problems in construction. The researches on negotiation support range from collaborative design to automated claim negotiation [12, 13]. Dzeng and Lin [14] presented an agent based system to help construction contractors negotiate with their suppliers via internet. Kim and Russel [15] developed a conceptual framework for intelligent earthwork systems to enhance the intelligence of constructions equipment. Kim and Paulson [16] presented an agent based compensatory negotiation methodology to facilitate the distributed coordination of project schedule changes. Yan et al [17] used multi-agent system to support project management in a distributed environment. Nassar [18] introduce a framework for managing a distributed project performance system using multi agent systems. Kedro [19] presented a distributed problem solving approach for collaborative multi disciplinary design in general and collaborative facility design and engineering in particular and propose agent based software integration. Halfawy [20] develops and implements a concurrent engineering methodology and a computational infrastructure that would enable these companies to share and exchange design and construction information. From the little amount of the support system applications, none of them applied negotiation support to the problem of multi-person and negotiation in MCDM for unfinished construction project. 


\section{UNFINISHED CONSTRUCTION PROJECT}

Construction works could be an unfinished project where it was abandoned or on-hold at some stage. Supply and demand problems in real estate market have left many residential and commercial projects "unfinished". The projects are buildings or other architectural structure, as a bridge, a road or a tower. A project becomes unfinished at various stages of development. The stage of the project may be currently being built or which construction work progresses extremely slowly. The work may be finished as a blueprint or whiteprint and never be realized, or be abandoned during construction.

While owners are hoping to sell, investors are looking for deals. Construction companies are looking for projects to complete. Unfinished construction carries a multiplier effect on job creation that begins with the investor outsourcing to a contractor to develop the construction site. Experience showed that potential buyers are more interested in buying assets, commercial space, or an unfinished construction site rather than functioning enterprises. Cost of unfinished construction will influence to cost of construction project. Issue the actual cost of work already done under the beginning of unfinished construction cost, current actual production costs and the end of unfinished construction costs calculated. Taken after completion of a settlement project, it has finished actual cost of the project.

In this paper, decision to unfinished construction is making the choice on termination decisions and delays, while on the other hand making the selection decision for the continuation of priority projects as part of a property that has been developed. With company's resource limits, then make the decision is not easy because it is very complex and strategic nature, which means the company, will determine the continuation. Therefore it is necessary to construct an alternative optimization that brings the best of existing resources. In addition to practical reality in the world, from the academic side, the delay of the project is an important part in a project management strategy, especially in an effort to control changes as part of the management integration, with all the causes and strategies to do so. Delays are also to be one discipline in decision making that can be resolved through a quantitative approach [30].

The decision on delays and selection of priorities during the construction phase is a complex problem. It preceded by an assessment of project success as control changes. Studies on these subjects are very rarely found in practical world. It is about exploring facts of the steps undertaken a developer in rescue project or the factors that underlie and influence decision-making, including the development of alternatives. In the academic world, research on the subject is inserted into discussion of project termination as part of project control and project completion [28] but not specifically on the approach to project delays.

There are two approaches on unfinished construction project decision. First is evaluation of success and failure of a project, second is the decision to continue, postpone or terminated. The approach is part of project controlling strategy [29]. In a settlement decision strategy there are four projects strategies including delay [26] namely "with the execution", "made in-house projects", "merger" and "termination" project. This strategy is a decision concerning selection criteria and forecasting [28] and in a case of multi multi-criteria decision research [27]. There are two important decisions in the analysis of project delays [26] which are first, decision on project success through several factors (characteristics of the project, contract, project participation and an interactive process) [25]. All of which are based on performance indicators that include cost, time, value and effectiveness [31]. The second decision is the determination of the delay of the project itself.

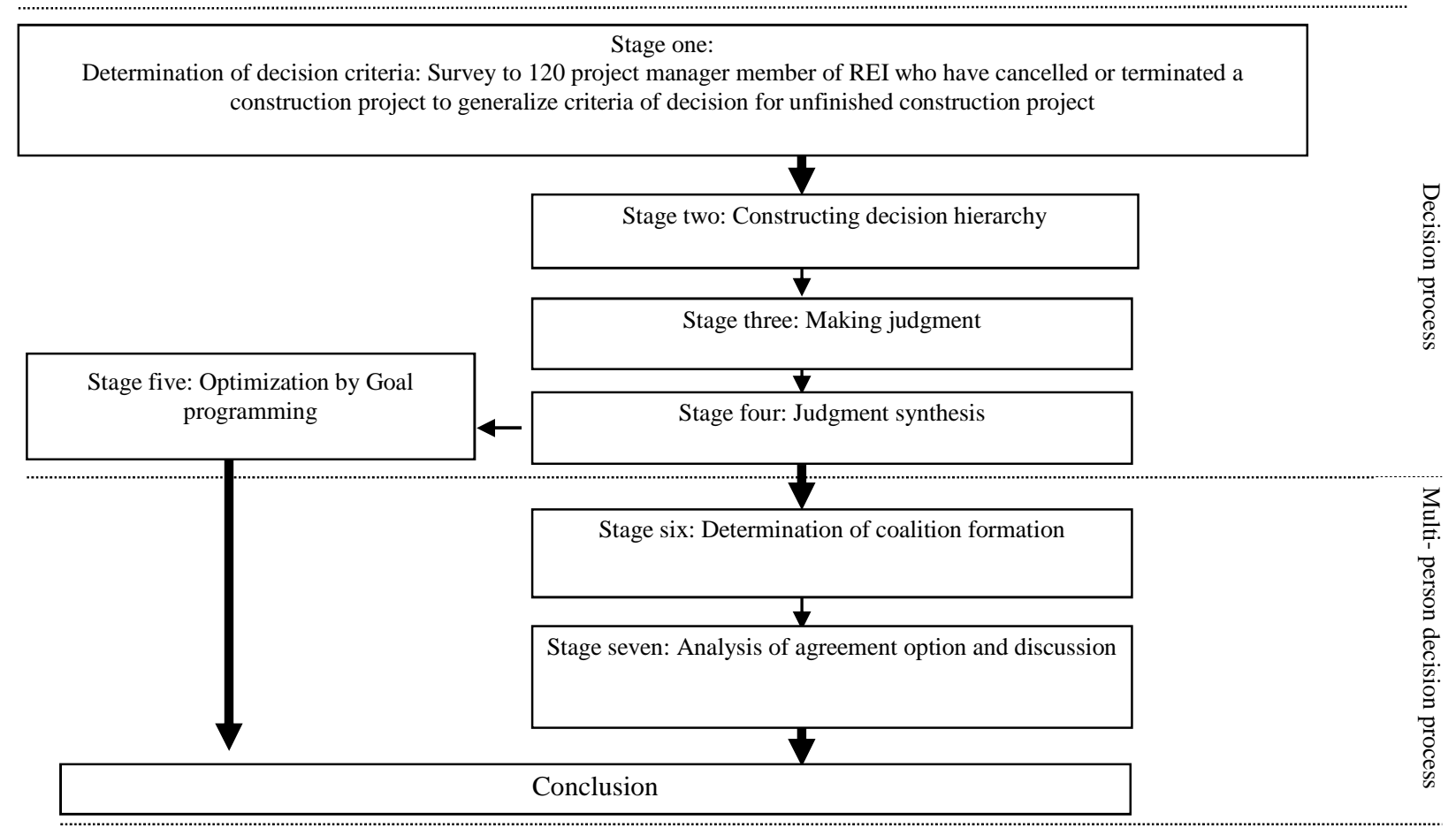

Fig. 1. Process of the group decision and negotiation support 


\section{METHOD}

This paper presents the research objective to develop a model of multi-person decision to fundamental problems involving decision of unfinished construction project. The model is based on a theoretical approach for developing a more effective collaboration and negotiation methodology. This paper also investigates the perspective of decision makers who have cancelled or terminated a construction project. The methodology applied in this paper combines methods for decision process and multi-person process. Analytical Hierarchy Process (AHP) [21] is for decision process. The AHP can be used successfully with a group [22] and negotiation [23]. A Coalition-based Game Theory [24] is for multiperson process. In this research there are five stakeholders as decision makers who give their preference on prioritizing criteria and prioritizing alternative for each criterion. The five stakeholders are Project Manager (PM) representing Client; Estate Manager (EM) who responsible on operational and maintenances of whole Estate and particular project; Architect; in house Design Manager (DM), and Quantity Surveyor (QS).

Fig. 1 represents the process. The process consists of two steps namely decision process and multi-person decision process. It consists of seven stages based on the methodology. The first stage is to determine the criteria for decision hierarchy. These are obtained from a survey study conducted in Indonesia Property Company. Stage two to Stage four are decision process by applying AHP to get prioritization of decision for each decision maker. Stage five is optimization for portfolio analysis. Stage six and seven are multi-person decision process. Result from this process is the group 'best option' for each project alternative to be decided whether the project is continued, postponed or terminated.

\section{RESULT AND DISCUSSION}

The propose model is implemented in one of the biggest private construction projects in Indonesia. The group decision consists of five stakeholders and five project alternatives. In this section the result presented in Stage two to four is only from one stakeholder preference that is Architect. The other stakeholder's preference is analyzed by same way. Results from all stakeholders are analyzed in Stage six and seven for the process of multiperson decision. The result is presented in Table 4. All process of the model (See Fig.1) is discussed in this section.

\section{A. Stage One: Decision Criteria for Unfinished Construction Project}

Determination of hierarchical problems is obtained through analyzing and testing of questionnaire survey concerning decision-maker opinions. Opinions were given in a five-point scale (1, not important; 2 , slightly important; 3 , somewhat important; 4 , important; 5 , very important). The questionnaire was then distributed to 120 members of REI (Real Estate Indonesia) randomly selected. Table 1 presents list of criteria for unfinished construction project decision. The list of criteria comes from compilation of previous study on project selection [25-31].These criteria and sub criteria resulted from the survey (Table 1) will be criteria and sub criteria on decision hierarchy (See Fig. 2) and called $\mathrm{c} 1$ for cost, $\mathrm{c} 2$ for time, $\mathrm{c} 3$ for technical, $\mathrm{c} 4$ for benefit, $\mathrm{c} 5$ for business and risk, c6 for marketing, and c7 for finance.

TABLE 1.

DECISION CRITERIA FOR UNFINISHED CONSTRUCTION PROJECTS

\begin{tabular}{|c|c|c|}
\hline Criteria/ Sub criteria & Mean & Standard Deviation \\
\hline $\begin{array}{l}\text { Time (c2) } \\
\text { Construction schedule, construction schedule variance }\end{array}$ & 4.50 & 0.644 \\
\hline $\begin{array}{l}\text { Business and Risk (c5) } \\
\text { Consumer image; long term business objectives; adaptation to focus of } \\
\text { business; change on project market; Financial risk of development, delay } \\
\text { effects to housing market }\end{array}$ & 4.25 & 0.949 \\
\hline $\begin{array}{l}\text { Finance (c7) } \\
\text { Available funds for OandM; Probability to capital return; effects to cash } \\
\text { flow; financial benefits; time to breakeven; financial competence }\end{array}$ & 4.20 & 0.834 \\
\hline $\begin{array}{l}\text { Benefit (c4) } \\
\text { Benefit to project market value; social benefit of the facilities }\end{array}$ & 4.15 & 0.745 \\
\hline $\begin{array}{l}\text { Technical (c3) } \\
\text { Possibility to be worked out; contractors arrangements; technical impact } \\
\text { of termination; construction material availability; legal aspect of technical } \\
\text { matter }\end{array}$ & 4.15 & 0.856 \\
\hline $\begin{array}{l}\text { Cost }(\mathrm{c} 1) \\
\text { Construction cost, construction cost variance }\end{array}$ & 4.10 & 0.745 \\
\hline $\begin{array}{l}\text { Marketing (c6) } \\
\text { Potential market; consumer acceptance; effect on housing sale; in } \\
\text { compliance with housing. }\end{array}$ & 3.90 & 0.832 \\
\hline
\end{tabular}




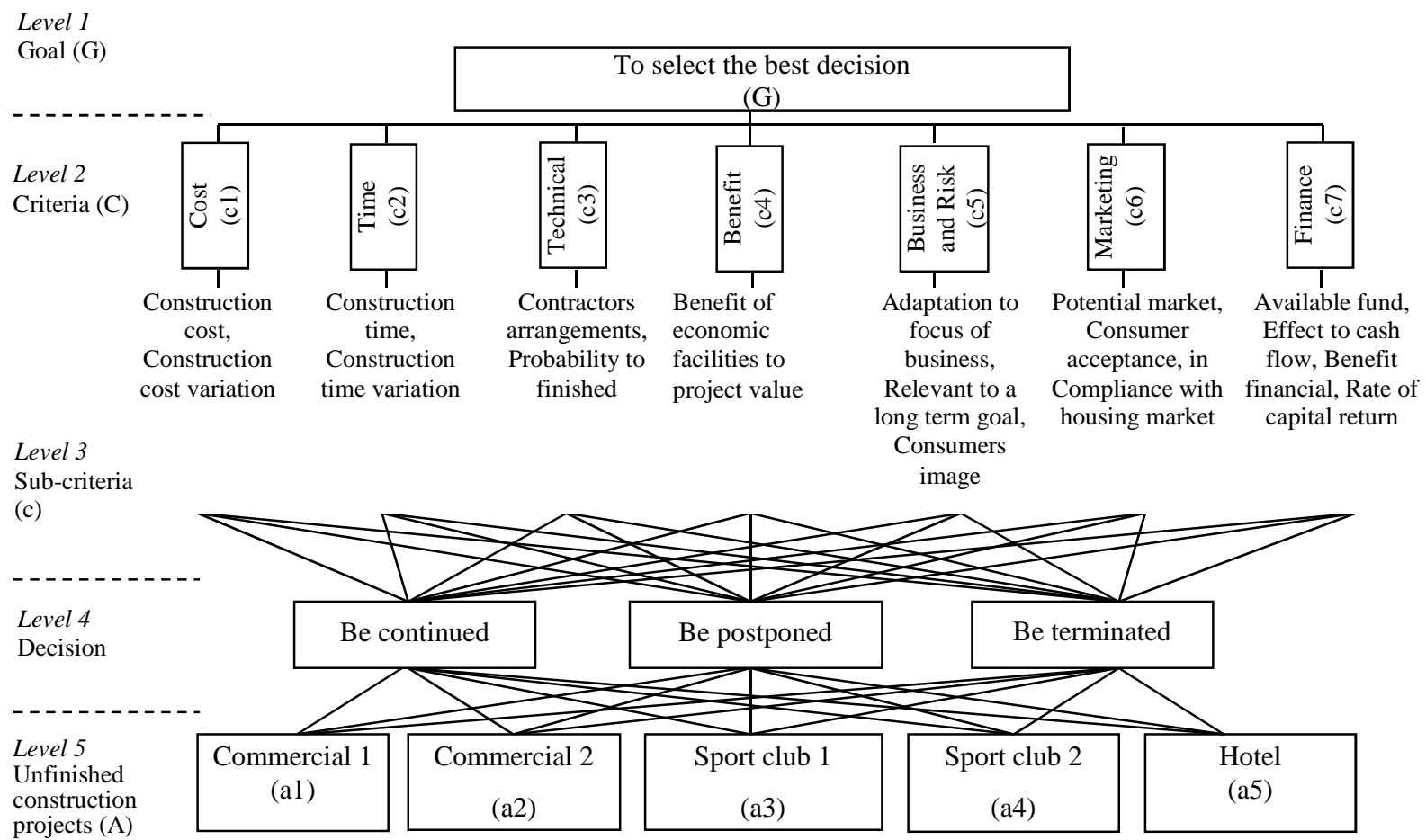

Fig. 2. Decision hierarchy for project selection

\section{B. Stage Two: Constructing Decision Hierarchy}

To obtain a good representation of a problem, it has to be structured into different components called activities. Fig. 2 shows five level of decision hierarchy. The goal of the problem $(\mathrm{G}=$ "to select the best decision for unfinished constructed project") is addressed by some alternatives $(A=a 1 ; a 2 ; a 3 ; a 4 ; a 5)$. The problem is split into sub-problems $(\mathrm{c} 1 ; \mathrm{c} 2 ; \mathrm{c} 3 ; \mathrm{c} 4 ; \mathrm{c5} ; \mathrm{c6} ; \mathrm{c} 7)$ which are criteria evaluating alternatives. These criteria (C) are split in sub-criteria. These criteria and sub criteria are determined from Stage one (See Table 1). On fourth level, there are three decision options, whether project will be continued, postponed or terminated. Fifth level of the decision hierarchy is the alternatives of unfinished construction project which are commercial project no.1, commercial project no.2, sport club project no.1, sport club project no.2, and hotel project.

\section{Stage Three: Making Judgment for Selecting Alternatives}

The first step in any MCDM problem is to define a set of alternatives and a set of decision criteria that the alternatives need to be evaluated with. The task appeals more to an art aspect of MCDM than to a science one [32]. Another very critical step of any MCDM problem is to accurately estimate the pertinent data. In this context, Triantaphyllou [33] argue that "very often in MCDM problems the data cannot be known in terms of absolute values". Therefore many decision making methods attempt to determine the relative importance, or weight, of the alternatives in terms of each criterion involved in a given MCDM problem. AHP [21] decompose a complex MCDM problem into a system of hierarchies. By reducing complex decisions to a series of one-on-one comparison, then synthesizing the result, AHP provides a clear rationale for it being declared the best decision. The AHP [21] is a framework of logic and problem resolving achieved by organizing perceptions, feelings, judgments, and memories into a hierarchy of forces that influences decision result. The final step in the AHP deals with the structure of an $m \times n$ matrix (where $m$ is the number of alternatives and $n$ is the number of criteria). The matrix is constructed by using the relative importance of the alternatives in terms of each criterion. The vector $\left(\mathrm{a}_{\mathrm{i} 1}, \mathrm{a}_{\mathrm{i} 2}, \mathrm{a}_{\mathrm{i} 3}, \ldots, \mathrm{a}_{\mathrm{im}}\right)$ for each $i$ is the principal eigenvector of a $n \times n$ reciprocal matrix which is determined by pair-wise comparisons of the impact of the $m$ alternatives on the $i$ - $t$ criterion.

The relative importance of pair-wise comparison [21] could be: equal (1), moderate (3), strong (5), very strong, demonstrated (7) or extreme (9). Sometimes one needs compromise judgments $(2,4,6,8)$ or reciprocal values $(1 / 9,1 / 8,1 / 7,1 / 6,1 / 5,1 / 4,1 / 3,1 / 2)$. For pair-wise comparisons between $n$ similar activities with respect to the criterion ck, a matrix $A_{\mathrm{ck}}=\left(a_{\mathrm{ij}}\right) i ; j$._n is a preferred form. If there are " $n$ " items that need to be compared for a given matrix, a total of $n(n-1) / 2$ judgments are needed. Then, the product of relative importance for each row of alternatives and criteria is calculated by the following equation:

$m_{i}=\prod_{j=1}^{n} a_{i j}(i=1,2, \ldots, n)$

Afterwards, the normalization will determine the weights of alternatives and decision criteria by:

$w_{i}=\frac{\bar{w}_{i}}{\sum_{i=1}^{n} \bar{w}_{i}}(i=1,2, \ldots, n)$

The process of making judgment in the group decision consists of two kinds which are weighting process of each alternative to each criterion and weighting process of each criterion to each decision maker. Table 2 presents a process of making judgment by AHP for each alternative to each criterion for one decision maker that is Architect and one decision that is 'project to be continued'. 
IPTEK, The Journal for Technology and Science, Vol. 21, No. 2, May 2010

TABLE 2.

ARCHITECT's PAIR WISE COMPARISON FOR ALTERNATIVES TO ALL CRITERIA (PROJECT TO BE CONTINUED)

\begin{tabular}{|c|c|c|c|c|c|c|c|c|c|c|c|c|}
\hline Cost & a1 & a2 & a3 & $\mathrm{a} 4$ & a5 & a1 & a2 & a3 & $\mathrm{a} 4$ & a5 & å & Weighting \\
\hline commercial 1 & 1.000 & 3.000 & 1.000 & 0.333 & 5.000 & 0.181 & 0.222 & 0.181 & 0.169 & 0.250 & 1.002 & 0.200 \\
\hline commercial 2 & 0.333 & 1.000 & 0.333 & 0.167 & 2.000 & 0.060 & 0.074 & 0.060 & 0.084 & 0.100 & 0.379 & 0.076 \\
\hline sport club 1 & 1.000 & 3.000 & 1.000 & 0.333 & 5.000 & 0.181 & 0.222 & 0.181 & 0.169 & 0.250 & 1.002 & 0.200 \\
\hline sport club 2 & 3.000 & 6.000 & 3.000 & 1.000 & 7.000 & 0.542 & 0.444 & 0.542 & 0.506 & 0.350 & 2.385 & 0.477 \\
\hline \multirow[t]{2}{*}{ hotel } & 0.200 & 0.500 & 0.200 & 0.143 & 1.000 & 0.036 & 0.037 & 0.036 & 0.072 & 0.050 & 0.232 & 0.046 \\
\hline & 5.533 & 13.500 & 5.533 & 1.976 & 20.000 & & & & & & & \\
\hline Time & $\mathrm{a} 1$ & $\mathrm{a} 2$ & a3 & $\mathrm{a} 4$ & a5 & $\mathrm{a} 1$ & $\mathrm{a} 2$ & $\mathrm{a} 3$ & $\mathrm{a} 4$ & $\mathrm{a} 5$ & å & Weighting \\
\hline commercial 1 & 1.000 & 0.250 & 2.000 & 0.167 & 0.500 & 0.074 & 0.066 & 0.111 & 0.083 & 0.051 & 0.385 & 0.077 \\
\hline commercial 2 & 4.000 & 1.000 & 5.000 & 0.500 & 3.000 & 0.296 & 0.264 & 0.278 & 0.249 & 0.305 & 1.392 & 0.278 \\
\hline sport club 1 & 0.500 & 0.200 & 1.000 & 0.143 & 0.333 & 0.037 & 0.053 & 0.056 & 0.071 & 0.034 & 0.250 & 0.050 \\
\hline sport club 2 & 6.000 & 2.000 & 7.000 & 1.000 & 5.000 & 0.444 & 0.529 & 0.389 & 0.498 & 0.508 & 2.368 & 0.474 \\
\hline \multirow[t]{2}{*}{ hotel } & 2.000 & 0.333 & 3.000 & 0.200 & 1.000 & 0.148 & 0.088 & 0.167 & 0.100 & 0.102 & 0.604 & 0.121 \\
\hline & 13.500 & 3.783 & 18.000 & 2.010 & 9.833 & & & & & & & \\
\hline Technical & a1 & $\mathrm{a} 2$ & a3 & $\mathrm{a} 4$ & a5 & a1 & $\mathrm{a} 2$ & a3 & $\mathrm{a} 4$ & a5 & å & Weighting \\
\hline commercial 1 & 1.000 & 0.250 & 0.500 & 0.200 & 0.333 & 0.067 & 0.064 & 0.053 & 0.085 & 0.043 & 0.310 & 0.062 \\
\hline commercial 2 & 4.000 & 1.000 & 3.000 & 0.500 & 3.000 & 0.267 & 0.255 & 0.316 & 0.211 & 0.383 & 1.432 & 0.286 \\
\hline sport club 1 & 2.000 & 0.333 & 1.000 & 0.333 & 0.500 & 0.133 & 0.085 & 0.105 & 0.141 & 0.064 & 0.528 & 0.106 \\
\hline sport club 2 & 5.000 & 2.000 & 3.000 & 1.000 & 3.000 & 0.333 & 0.511 & 0.316 & 0.423 & 0.383 & 1.965 & 0.393 \\
\hline \multirow[t]{2}{*}{ hotel } & 3.000 & 0.333 & 2.000 & 0.333 & 1.000 & 0.200 & 0.085 & 0.211 & 0.141 & 0.128 & 0.764 & 0.153 \\
\hline & 15.000 & 3.917 & 9.500 & 2.367 & 7.833 & & & & & & & \\
\hline Benefit & a1 & a2 & a3 & a4 & a5 & a1 & a2 & a3 & a4 & a5 & å & Weighting \\
\hline commercial 1 & 1.000 & 5.000 & 3.000 & 7.000 & 0.333 & 0.214 & 0.303 & 0.315 & 0.292 & 0.187 & 1.310 & 0.262 \\
\hline commercial 2 & 0.200 & 1.000 & 0.333 & 2.000 & 0.143 & 0.043 & 0.061 & 0.035 & 0.083 & 0.080 & 0.302 & 0.060 \\
\hline sport club 1 & 0.333 & 3.000 & 1.000 & 5.000 & 0.200 & 0.071 & 0.182 & 0.105 & 0.208 & 0.112 & 0.678 & 0.136 \\
\hline sport club 2 & 0.143 & 0.500 & 0.200 & 1.000 & 0.111 & 0.031 & 0.030 & 0.021 & 0.042 & 0.062 & 0.186 & 0.037 \\
\hline \multirow[t]{2}{*}{ hotel } & 3.000 & 7.000 & 5.000 & 9.000 & 1.000 & 0.642 & 0.424 & 0.524 & 0.375 & 0.560 & 2.525 & 0.505 \\
\hline & 4.676 & 16.500 & 9.533 & 24.000 & 1.787 & & & & & & & \\
\hline Business Risk & a1 & $\mathrm{a} 2$ & a3 & $\mathrm{a} 4$ & a5 & a1 & a2 & a3 & a4 & a5 & å & Weighting \\
\hline commercial 1 & 1.000 & 0.500 & 3.000 & 0.500 & 3.000 & 0.176 & 0.115 & 0.214 & 0.197 & 0.316 & 1.019 & 0.204 \\
\hline commercial 2 & 2.000 & 1.000 & 3.000 & 0.500 & 2.000 & 0.353 & 0.231 & 0.214 & 0.197 & 0.211 & 1.206 & 0.241 \\
\hline sport club 1 & 0.333 & 0.333 & 1.000 & 0.200 & 0.500 & 0.059 & 0.077 & 0.071 & 0.079 & 0.053 & 0.339 & 0.068 \\
\hline sport club 2 & 2.000 & 2.000 & 5.000 & 1.000 & 3.000 & 0.353 & 0.462 & 0.357 & 0.395 & 0.316 & 1.882 & 0.376 \\
\hline \multirow[t]{2}{*}{ hotel } & 0.333 & 0.500 & 2.000 & 0.333 & 1.000 & 0.059 & 0.115 & 0.143 & 0.132 & 0.105 & 0.554 & 0.111 \\
\hline & 5.667 & 4.333 & 14.000 & 2.533 & 9.500 & & & & & & & \\
\hline Marketing & a1 & $\mathrm{a} 2$ & a3 & $\mathrm{a} 4$ & a5 & a1 & $\mathrm{a} 2$ & a3 & $\mathrm{a} 4$ & a5 & å & Weighting \\
\hline commercial 1 & 1.000 & 3.000 & 3.000 & 5.000 & 2.000 & 0.423 & 0.353 & 0.429 & 0.385 & 0.462 & 2.050 & 0.410 \\
\hline commercial 2 & 0.333 & 1.000 & 0.500 & 2.000 & 0.500 & 0.141 & 0.118 & 0.071 & 0.154 & 0.115 & 0.599 & 0.120 \\
\hline sport club 1 & 0.333 & 2.000 & 1.000 & 2.000 & 0.500 & 0.141 & 0.235 & 0.143 & 0.154 & 0.115 & 0.788 & 0.158 \\
\hline sport club 2 & 0.200 & 0.500 & 0.500 & 1.000 & 0.333 & 0.085 & 0.059 & 0.071 & 0.077 & 0.077 & 0.369 & 0.074 \\
\hline \multirow[t]{2}{*}{ hotel } & 0.500 & 2.000 & 2.000 & 3.000 & 1.000 & 0.211 & 0.235 & 0.286 & 0.231 & 0.231 & 1.194 & 0.239 \\
\hline & 2.367 & 8.500 & 7.000 & 13.000 & 4.333 & & & & & & & \\
\hline Finance & a1 & $\mathrm{a} 2$ & a3 & a4 & a5 & a1 & $\mathrm{a} 2$ & a3 & $\mathrm{a} 4$ & a5 & å & Weighting \\
\hline commercial 1 & 1.000 & 2.000 & 3.000 & 2.000 & 3.000 & 0.375 & 0.444 & 0.400 & 0.267 & 0.333 & 1.819 & 0.364 \\
\hline commercial 2 & 0.500 & 1.000 & 2.000 & 2.000 & 2.000 & 0.188 & 0.222 & 0.267 & 0.267 & 0.222 & 1.165 & 0.233 \\
\hline sport club 1 & 0.333 & 0.500 & 1.000 & 2.000 & 1.000 & 0.125 & 0.111 & 0.133 & 0.267 & 0.111 & 0.747 & 0.149 \\
\hline sport club 2 & 0.500 & 0.500 & 0.500 & 1.000 & 2.000 & 0.188 & 0.111 & 0.067 & 0.133 & 0.222 & 0.721 & 0.144 \\
\hline hotel & 0.333 & 0.500 & 1.000 & 0.500 & 1.000 & 0.125 & 0.111 & 0.133 & 0.067 & 0.111 & 0.547 & 0.109 \\
\hline
\end{tabular}

The result is presented in Fig. 3. For the other decision (project to be terminated and project to be postponed) and the other decision maker (PM, EM, DM, and QS), the process are presented as a result on Table 4.

Table 2 and Fig. 3 show a sample of Architect's judgment. Architect's pair wise comparison to all criteria presents the best project to be continued to each criterion. Observe that in criteria cost, the best project to be continued is sport club 2, mean while hotel is the best project to be continued for criteria benefit.

\section{Stage Four: Judgment Synthesis}

From equation (2), the matrix of weights of alternatives (under each decision criterion) and decision criteria, $W=$ $\left[w_{1}, w_{2}, \ldots, w_{n}\right]^{\mathrm{T}}$, is formed. Gathering the weights of all alternatives under each decision criterion $i$, for $i \in[1, n]$, a matrix of weights of alternatives under all decision criteria, $H$, is formed. In addition, a matrix $\mathrm{R}$ is also formed for all decision criteria $R=\left[w_{1}, w_{2}, \ldots, w_{i}, \ldots, w_{n}\right]^{\mathrm{T}}$. The matrix of alternative final score, $S$, is calculated by the product of the two matrices $H$ and $R$. Finally, the best solution of a problem is determined by finding the maximum value of $S$ matrix, i.e. $\max \left(s_{1}, s_{2}, \ldots, \mathrm{s}_{\mathrm{n}}\right)$. If $n$ is the size of the pair wise comparison matrix $\mathrm{A}_{\mathrm{ck}}=\left(a_{\mathrm{ij}}\right)$ $i ; j_{-} n$, the Eigen vector which is associated represents the priorities of the activities with respect to $\mathrm{ck}\left(\mathrm{W}_{\mathrm{ck}}=\right.$ $\left.\left(w_{i}\right) i_{-} n\right)$. The AHP [21] measures the overall consistency of judgments by means a consistency ratio: C.R.A $A_{c k}=$ C.I. $A_{c k}=R . C_{n}$. The higher the consistency ratio, the less consistent the preferences are. The value of the consistency ratio should be $10 \%$ or less. Under this condition the priorities can be calculated. Table 3 presents the process of judgment synthesis of one decision maker that is Architect. From the Table, it can be concluded that Architect prioritizes the Commercial 1 to be continued and the Hotel to be postponed or terminated.

By same method, the decision from the other four stakeholders can be calculated. The result is presented in Fig. 4 and Fig. 6. 
IPTEK, The Journal for Technology and Science, Vol. 21, No. 2, May 2010

TABLE 3 .

SYNTHESIS OF PREFERENCE OF AN ARCHITECT

Decision 1: To be Continued

\begin{tabular}{|c|c|c|c|c|c|c|c|c|c|}
\hline \multirow{2}{*}{$\begin{array}{l}\text { The Unfinished } \\
\text { Construction } \\
\text { Project }\end{array}$} & \multicolumn{7}{|c|}{ Criteria and the Weighting } & \multirow[b]{2}{*}{ Weight } & \multirow[b]{2}{*}{ Rank } \\
\hline & $\begin{array}{c}\text { Cost } \\
(0.05399)\end{array}$ & $\begin{array}{c}\text { Time } \\
(0.02794)\end{array}$ & $\begin{array}{l}\text { Technical } \\
(0.15332)\end{array}$ & $\begin{array}{c}\text { Benefit } \\
(0.19394)\end{array}$ & $\begin{array}{c}\text { Business } \\
(0.15329)\end{array}$ & $\begin{array}{c}\text { Marketing } \\
(0.36413)\end{array}$ & $\begin{array}{c}\text { Finance } \\
(0.05341)\end{array}$ & & \\
\hline Commercial 1 & 0.1404 & 0.12428 & 0.5049 & 0.2856 & 0.2313 & 0.23645 & 0.4426 & 0.2891 & $1^{\mathrm{st}}$ \\
\hline Commercial 2 & 0.0759 & 0.24219 & 0.2586 & 0.1182 & 0.3319 & 0.2935 & 0.2791 & 0.2461 & $3^{\text {rd }}$ \\
\hline Sport Club 1 & 0.4583 & 0.50158 & 0.1274 & 0.2273 & 0.1854 & 0.30693 & 0.0999 & 0.2479 & $2^{\text {nd }}$ \\
\hline Sport Club 2 & 0.2529 & 0.07136 & 0.0546 & 0.3212 & 0.1566 & 0.11301 & 0.1334 & 0.1586 & $4^{\text {th }}$ \\
\hline Hotel & 0.0725 & 0.06059 & 0.0546 & 0.0477 & 0.0949 & 0.05011 & 0.0449 & 0.0584 & $5^{\text {th }}$ \\
\hline \multicolumn{10}{|c|}{ Decision 2: To be Postponed } \\
\hline \multirow{2}{*}{$\begin{array}{l}\text { The Unfinished } \\
\text { Construction } \\
\text { Project }\end{array}$} & \multicolumn{7}{|c|}{ Criteria and the Weighting } & \multirow[b]{2}{*}{ Weight } & \multirow[b]{2}{*}{ Rank } \\
\hline & $\begin{array}{c}\text { Cost } \\
(0.05399) \\
\end{array}$ & $\begin{array}{c}\text { Time } \\
(0.02794)\end{array}$ & $\begin{array}{l}\text { Technical } \\
(0.15332)\end{array}$ & $\begin{array}{c}\text { Benefit } \\
(0.19394)\end{array}$ & $\begin{array}{c}\text { Business } \\
(0.15329)\end{array}$ & $\begin{array}{l}\text { Marketing } \\
(0.36413)\end{array}$ & $\begin{array}{l}\text { Finance } \\
(0.05341)\end{array}$ & & \\
\hline Commercial 1 & 0.2603 & 0.17711 & 0.0521 & 0.0390 & 0.2589 & 0.09718 & 0.0820 & 0.1140 & $4^{\text {th }}$ \\
\hline Commercial 2 & 0.4484 & 0.09467 & 0.2746 & 0.1443 & 0.0944 & 0.11708 & 0.1711 & 0.1632 & $2^{\text {nd }}$ \\
\hline Sport Club 1 & 0.1618 & 0.04592 & 0.1505 & 0.1986 & 0.0946 & 0.08863 & 0.1088 & 0.1242 & $5^{\text {th }}$ \\
\hline Sport Club 2 & 0.0797 & 0.22288 & 0.0838 & 0.1085 & 0.1745 & 0.19925 & 0.1927 & 0.1540 & $3^{\text {rd }}$ \\
\hline Hotel & 0.0496 & 0.45953 & 0.4387 & 0.5093 & 0.3774 & 0.49789 & 0.4451 & 0.4444 & $1^{\mathrm{st}}$ \\
\hline \multicolumn{10}{|c|}{ Decision 3: To be Terminated } \\
\hline \multirow{2}{*}{$\begin{array}{c}\text { The Unfinished } \\
\text { Construction } \\
\text { Project }\end{array}$} & \multicolumn{7}{|c|}{ Criteria and the Weighting } & \multirow[b]{2}{*}{ Weight } & \multirow[b]{2}{*}{ Rank } \\
\hline & $\begin{array}{c}\text { Cost } \\
(0.05399)\end{array}$ & $\begin{array}{c}\text { Time } \\
(0.02794)\end{array}$ & $\begin{array}{l}\text { Technical } \\
(0.15332)\end{array}$ & $\begin{array}{c}\text { Benefit } \\
(0.19394)\end{array}$ & $\begin{array}{c}\text { Business } \\
(0.15329)\end{array}$ & $\begin{array}{c}\text { Marketing } \\
(0.36413)\end{array}$ & $\begin{array}{l}\text { Finance } \\
(0.0534)\end{array}$ & & \\
\hline Commercial 1 & 0.09156 & 0.17631 & 0.0435 & 0.0677 & 0.1584 & 0.09014 & 0.0636 & 0.0902 & $5^{\text {th }}$ \\
\hline Commercial 2 & 0.56444 & 0.06778 & 0.0840 & 0.2350 & 0.1067 & 0.07331 & 0.0779 & 0.1380 & $4^{\text {th }}$ \\
\hline Sport Club 1 & 0.23227 & 0.03482 & 0.1674 & 0.1144 & 0.1593 & 0.12513 & 0.2036 & 0.1422 & $3^{\text {rd }}$ \\
\hline Sport Club 2 & 0.05711 & 0.21827 & 0.2860 & 0.0799 & 0.1407 & 0.20619 & 0.1977 & 0.1757 & $2^{\text {nd }}$ \\
\hline Hotel & 0.05463 & 0.50282 & 0.4189 & 0.5028 & 0.4346 & 0.50522 & 0.4570 & 0.4537 & $1^{\mathrm{st}}$ \\
\hline
\end{tabular}

\section{E. Stage Five: Optimization}

Goal Programming (GP) [34] is used for decision optimization before decision makers form a coalition for a negotiation. GP is an approach to optimize a set of objective function subject to constraint. The outcome is perceived as indicating the tradeoffs that need to be made in terms of reducing a certain objective in return for an increase in some other objectives [35]. Based on the values of aggregation five decision makers, by project decomposition and decision alternatives, optimization variables can be set as the following result: $\mathrm{X}_{1,1}$ (commercial 1 project will be continued); $\mathrm{X}_{1,2}$ (commercial 1 project will be postponed); $\mathrm{X}_{1,3}$ (commercial 1 project will be terminated); $\mathrm{X}_{2,1}$ (commercial 2 project will be continued); $\mathrm{X}_{2,2}$ (commercial 2 will be postponed); $\mathrm{X}_{2,3}$ (commercial 2 project will be terminated); $\mathrm{X}_{3,1}$ (sport club 1 project will be continued); $\mathrm{X}_{3,2}$ (sport club 1 project will be postponed); $\mathrm{X}_{3,3}$ (sport club 1 project will be terminated); $\mathrm{X}_{4,1}$ (sport club 2 project will be continued); $\mathrm{X}_{4,2}$ (sport club 2 project will be postponed); $\mathrm{X}_{4,3}$ (sport club 2 project will be terminated); $\mathrm{X}_{5,1}$ (hotel project will be continued); $\mathrm{X}_{5,2}$ (hotel project will be postponed); $\mathrm{X}_{5,3}$ (hotel project will be terminated).

Constraint of goal objective function is decision cost of each project.

Fifteen functions of cost are presented in Equation (3). The value of each decision is calculated based on engineering estimation.

(In Million USD)
$\mathrm{X}_{1,1}+\mathrm{d}_{1}{ }^{-}-\mathrm{d}_{1}^{+}=10.4$ if project of commercial 1 is continued $\mathrm{X}_{1,2}+\mathrm{d}_{2}^{-}-\mathrm{d}_{2}^{+}=5.24$ if project of commercial 1 is postponed $\mathrm{X}_{1,3}+\mathrm{d}_{3}^{-}-\mathrm{d}_{3}^{+}=1.8$ if project of commercial 1 is terminated $\mathrm{X}_{2,1}+\mathrm{d}_{4}{ }^{-}-\mathrm{d}_{4}{ }^{+}=10.5$ if project of commercial 2 is continued $\mathrm{X}_{2,2}+\mathrm{d}_{5}{ }^{-}-\mathrm{d} 5^{+}=4.37$ if project of commercial 2 is postponed $\mathrm{X}_{2,3}+\mathrm{d}_{6}{ }^{-}-\mathrm{d}_{6}{ }^{+}=6$ if project of commercial 2 is terminated $\mathrm{X}_{3,1}+\mathrm{d}_{7}^{-}-\mathrm{d}_{7}^{+}=3.5$ if project of sport club 1 is continued $\mathrm{X}_{3,2}+\mathrm{d}_{8}{ }^{-}-\mathrm{d}_{8}{ }^{+}=7$ if project of sport club 1 is postponed $\mathrm{X}_{3,3}+\mathrm{d}_{9}{ }^{-}-\mathrm{d}_{9}{ }^{+}=2.5$ if project of sport club 1 is terminated $\mathrm{X}_{4,1}+\mathrm{d}_{10}{ }^{-}-\mathrm{d}_{10}{ }^{+}=6.25$ if project of sport club2 is continued $\mathrm{X}_{4,2}+\mathrm{d}_{11}{ }^{-}-\mathrm{d}_{11}{ }^{+}=3.9$ if project of sport club 2 is postponed $\mathrm{X}_{4,3}+\mathrm{d}_{12}{ }^{-}-\mathrm{d}_{12}{ }^{+}=1.5$ if project of sport club 2 is terminated $\mathrm{X}_{5,1}+\mathrm{d}_{13}{ }^{-}-\mathrm{d}_{13}{ }^{+}=23.75$ if project of hotel is continued $\mathrm{X}_{5,2}+\mathrm{d}_{14}{ }^{-}-\mathrm{d}_{14}{ }^{+}=12.5$ if project of hotel is postponed $\mathrm{X}_{5,3}+\mathrm{d}_{15}{ }^{-}-\mathrm{d}_{15}{ }^{+}=1.25$ if project of hotel is terminated Where $\mathrm{di}^{-}, \mathrm{di}^{+} \geq 0$

Function of cost for all project alternatives is, $X_{1,1}+X_{2,1}+X_{3,1}+X_{4,1}+X_{5,1}+X_{1,2}+X_{2,2}+X_{3,2}+X_{4,2}+X_{5,2}+$ $\mathrm{X}_{1,3}+\mathrm{X}_{2,3}+\mathrm{X}_{3,3}+\mathrm{X}_{4,3}+\mathrm{X}_{5,3}+\mathrm{d}_{16}{ }^{-}-\mathrm{d}_{16}{ }^{+}=32.25$ Million USD.

Objectives function with preemptive priority,

$\mathrm{P} 1=$ Total cost function and

$\mathrm{P} 2$ = function of goal constraint every project is

Minimize:

$\mathrm{P}_{1}\left(\mathrm{~d}_{16}{ }^{+}\right)+\mathrm{P}_{2}\left(\mathrm{~A}_{1} \mathrm{~d}^{-}+\mathrm{A}_{2} \mathrm{~d}_{2}^{-}+\mathrm{A}_{3} \mathrm{~d}_{3}{ }^{-}+\mathrm{B}_{1} \mathrm{~d}_{4}{ }^{-}+\mathrm{B}_{2} \mathrm{~d}_{5}{ }^{-}+\mathrm{B}_{3} \mathrm{~d}_{6}{ }^{-}+\right.$ $\mathrm{C}_{1} \mathrm{~d}_{7}{ }^{-}+\mathrm{C}_{2} \mathrm{~d}_{8}{ }^{-}+\mathrm{C}_{3} \mathrm{~d}_{9}{ }^{-}+\mathrm{D}_{1} \mathrm{~d}_{10}{ }^{-}+\mathrm{D}_{2} \mathrm{~d}_{11}{ }^{-}+\mathrm{D}_{3} \mathrm{~d}_{12}{ }^{-}+\mathrm{E}_{1} \mathrm{~d}_{13}{ }^{-}+\mathrm{E}_{2} \mathrm{~d}_{14}{ }^{-}$ $+\mathrm{E}_{3} \mathrm{~d}_{15}{ }^{-}$)

By entering preference synthesis of project to alternative of decision (tables 3 ) the goal objective function can be formulated as follows:

Minimize:

$\mathrm{P}_{1}\left(\mathrm{~d}_{16}{ }^{+}\right)+\mathrm{P}_{2}\left(0.289041 \mathrm{~d}_{1}^{-}+0.114027 \mathrm{~d}_{2}{ }^{-}+0.090200 \mathrm{~d}_{3}^{-}+\right.$ $0.246093 \mathrm{~d}_{4}^{-}+0.163208 \mathrm{~d}_{5}^{-}+0.138061 \mathrm{~d}_{6}^{-}+0.247877 \mathrm{~d}_{7}^{-}+$ $0.12423 \mathrm{~d}_{8}^{-}+0.142237 \mathrm{~d}_{9}^{-}+0.158576 \mathrm{~d}_{10^{-}}+0.154046 \mathrm{~d}_{11}^{-}+$ $\left.0.175759 \mathrm{~d}_{12}{ }^{-}+0.058413 \mathrm{~d}_{13}{ }^{-}+0.444489 \mathrm{~d}_{14}{ }^{-}+0.453743 \mathrm{~d}_{15}{ }^{-}\right)$(6) 
Solution of the optimization was concluded for each project: commercial 1 project is decided to continue; project of commercial 2 is decided to continue, sport club 1 is selected and decided to continue; sport club 2 is decided to postpone; and hotel is decided to terminate. The total cost is 29.55 Million USD. The decision and solution has been based on cost constraint. The constraint was limited to a project total cost of 32.25 Million USD.

\section{F. Stage Six: Determination of Coalition Formation}

Decision makers may choose to cooperate by forming coalitions. Coalition is formed in order to benefit every member of the coalition so that all might receive more than they could individually on their own. Coalition has been used in many researches in negotiation. In this paper, the coalition formation process consists of determination of coalition formation and analysis of agreement options. It considered a game in which the players (decision makers) may choose to cooperate by forming coalitions. Coalition has been used in many researches in cooperative games such as [36] for cooperative information agent-based systems and [23] for COTS selection. Cooperation is the nature in team work on operation and construction management [27], [37] and [38]. A coalition [22] is any subset $\mathrm{C} \subset \mathrm{N}$, or numbered collection of players in which there are $n>1$ player numbered $1,2 \ldots \mathrm{n}$ and set of all the players $\mathrm{N}=$ $\{1,2, \ldots, n\}$. Coalition is formed by making binding agreements in order to benefit every member of the coalition so that all members might receive more than they could individually on their own. Von Neumann and Morgensten [39] express the characteristic function called super-additive as follow:

$$
v(S \cup T) \geq v(S)+v(T) \text { For all } S, T \subset N, S \cap T=\phi
$$

Since there are $2^{\mathrm{n}}$ possible subsets of $N$, there are $2^{\mathrm{n}}$ possible coalitions. In every coalition [22] and [40] note that there is empty coalition that is a coalition made up of no members (the null set $\phi$ ) and a grand coalition $\mathrm{N}$ consisting of all the players. The benefit of a coalition can be quantified through the use of characteristic function. The characteristic function of a coalition $\mathrm{C} \subset \mathrm{N}$ is the largest guaranteed payoff to the coalition. A characteristic function of an $n$-person cooperative game can be denoted by equation as follow:

$v(\phi)=0$ and $v(N) \geq i=\sum_{i=1}^{n} v(i)$

A coalition structure is a means of describing how the players divide themselves into mutually exclusive coalitions.

It can be described by a set $S=\left\{S_{1}, S_{2}, \ldots, S_{m}\right\}$ of the $m$ coalition that is formed.

The set $S$ is a partition of $\mathrm{N}$ that satisfies three conditions:

$\mathrm{S}_{\mathrm{j}} \neq 0, \mathrm{j}=1, \ldots, \mathrm{m}$

$\mathrm{S}_{\mathrm{i}} \cap \mathrm{S}_{\mathrm{f}}=\phi$, for all $\mathrm{i}=\mathrm{j}$, and

$\bigcup_{S_{j} \in S} S_{j}=N$
It means that each player belongs to one and only one of the $m$ nonempty coalitions within the coalition structure and also none of the players in any coalition $m$ is connected to other players not in the coalition. This axiom is an axiom that the characteristic function in all must be super-additive, with the assumption of supperadditive, the players have the incentive to form and joint the grand coalition $N$.

The quantitative representation of a player's outcome at the end of a game is called payoff. The collection of payoffs to all players may be expressed as the row vector $\bar{x}=\left(\mathrm{x}_{\mathrm{A}}, \mathrm{x}_{\mathrm{B}}, \ldots, \mathrm{x}_{\mathrm{n}}\right)$ of each player's payoff. As the negotiation progress, the preferences of the evaluation criteria change, leading to changing score of the solution of alternative decision for unfinished construction project, and changing membership and size of the set of agreement options. Three stages are conducted to determine agreement options which are;

1. Determining the weighting factor (weight of preferences) of criteria for each stakeholder. Fig.4 reveals different preferences among decision makers (SH1SH5).

2. Grading of alternative for each evaluation criteria. Fig. 5 presents that a5 is the 'best fit' for $\mathrm{c} 2, \mathrm{c} 3, \mathrm{c} 4$, c5, a6 and c7. The 'best fit' solution for $\mathrm{c} 1$ is a2.

3. Scoring of every alternative for every decision maker. Fig. 6 shows that decision makers have different best option as a solution project for the decision to terminate.

\section{G. Stage Seven: Analysis of Agreement Options and Discussion}

Game theory [22] techniques for coalition formation have been applied. Works in game theory describe which coalition will form in $n$-person games under different setting and how the players will distribute the benefits of the cooperation among themselves [41]. The proposed coalition formation model enables each agent to select individually its allies or coalition. Table 4 shows the alternative ranking from possibility of coalition among decision makers for each decision. Firstly, individually all stakeholders have their own best solution. Finally, as shown on Table 4, a4 is found to be the 'best fit' solution for all stakeholders to be continued, a3 is the best option to be postponed, and a5 is the best option to be terminated.

Coalition formation in characteristic function game includes three activities which are coalition structure generation, solving the optimization problem of each coalition, and dividing payoff/the value of the generated solution. This game with five decision makers, there are 32 possible ( subset of $5=2^{\mathrm{N}}$ ) coalitions including empty coalition and five singleton coalitions. The coalition's objective is to maximize value. In this case, coalition is happen in three condition of decision which is to be continued, to be postponed, and to be terminated for each alternative of unfinished construction project.

To maximize value also means that each alternative can only be decided in one decision. 
IPTEK, The Journal for Technology and Science, Vol. 21, No. 2, May 2010

TABLE 4.

RANKING OF ALternatives FROM POSSIBILITY OF COALITION FOR EACH DECISION

\begin{tabular}{|c|c|c|c|c|c|c|c|c|c|c|c|c|c|c|c|}
\hline \multirow{2}{*}{$\begin{array}{l}\text { Ranking of Alternatives for Each Person } \\
\text { and Their Coalition }\end{array}$} & \multicolumn{5}{|c|}{ Be Continued } & \multicolumn{5}{|c|}{ Be Postponed } & \multicolumn{5}{|c|}{ Be Terminated } \\
\hline & a1 & a2 & $\mathrm{a} 3$ & $\mathrm{a} 4$ & a5 & $\mathrm{a} 1$ & $\mathrm{a} 2$ & $\mathrm{a} 3$ & $\mathrm{a} 4$ & a5 & a1 & a2 & a3 & $\mathrm{a} 4$ & a5 \\
\hline Decision Maker (SH) 1 (Architect) & $1^{\mathrm{st}}$ & $3^{\text {rd }}$ & $2^{\text {nd }}$ & $4^{\text {th }}$ & $5^{\text {th }}$ & $4^{\text {th }}$ & $2^{\text {nd }}$ & $5^{\text {th }}$ & $3^{\text {rd }}$ & $1^{\mathrm{st}}$ & $5^{\text {th }}$ & $4^{\text {th }}$ & $3^{\text {rd }}$ & $2^{\text {nd }}$ & $1^{\mathrm{st}}$ \\
\hline Decision Maker (SH) 2 (PM) & $4^{\text {th }}$ & $2^{\text {nd }}$ & $4^{\text {th }}$ & $3^{\text {rd }}$ & $1^{\mathrm{st}}$ & $5^{\text {th }}$ & $1^{\text {st }}$ & $3^{\text {rd }}$ & $2^{\text {nd }}$ & $4^{\text {th }}$ & $2^{\text {nd }}$ & $5^{\text {th }}$ & $3^{\text {rd }}$ & $4^{\text {th }}$ & $1^{\mathrm{st}}$ \\
\hline Decision Maker (SH) 3 (DM) & $3^{\text {rd }}$ & $2^{\text {nd }}$ & $5^{\text {th }}$ & $4^{\text {th }}$ & $1^{\text {st }}$ & $4^{\text {th }}$ & $1^{\mathrm{st}}$ & $3^{\text {rd }}$ & $2^{\text {nd }}$ & $5^{\mathrm{h}}$ & $1^{\text {st }}$ & $4^{\text {th }}$ & $3^{\text {rd }}$ & $5^{\mathrm{h}}$ & $2^{\text {nd }}$ \\
\hline Decision Maker (SH) 4 (EM) & $4^{\text {th }}$ & $2^{\text {nd }}$ & $3^{\text {rd }}$ & $5^{\text {th }}$ & $1^{\mathrm{st}}$ & $1^{\text {st }}$ & $3^{\text {rd }}$ & $2^{\text {nd }}$ & $5^{\text {th }}$ & $4^{\text {th }}$ & $3^{\text {rd }}$ & $5^{\text {th }}$ & $1^{\mathrm{st}}$ & $4^{\text {th }}$ & $2^{\text {nd }}$ \\
\hline Decision Maker (SH) 5 (C & $5^{\text {th }}$ & $3^{\text {rd }}$ & $4^{\text {th }}$ & $2^{\text {nd }}$ & $1^{\text {st }}$ & $5^{\mathrm{h}}$ & $1^{\mathrm{st}}$ & $3^{\text {rd }}$ & $2^{\text {nd }}$ & $4^{\text {th }}$ & $5^{\text {th }}$ & $3^{\text {rd }}$ & $1^{\mathrm{st}}$ & $4^{\text {th }}$ & $2^{\text {nd }}$ \\
\hline Coalition SH 1,2 & $4^{\text {th }}$ & $2^{\text {nd }}$ & $3^{\text {rd }}$ & $1^{\text {st }}$ & $5^{\text {th }}$ & $5^{\text {th }}$ & $4^{\text {th }}$ & $2^{\text {nd }}$ & $1^{\mathrm{st}}$ & $3^{\text {rd }}$ & $2^{\text {nd }}$ & $3^{\text {rd }}$ & $4^{\text {th }}$ & $5^{\text {th }}$ & $1^{\text {st }}$ \\
\hline Coalition SH 1,3 & $4^{\text {th }}$ & $2^{\text {nd }}$ & $3^{\text {rd }}$ & $1^{\text {st }}$ & $5^{\text {th }}$ & $4^{\text {th }}$ & $2^{\text {nd }}$ & $1^{\text {st }}$ & $3^{\text {rd }}$ & $5^{\text {th }}$ & $3^{\text {rd }}$ & $4^{\text {th }}$ & $2^{\text {nd }}$ & $5^{\text {th }}$ & $1^{\mathrm{st}}$ \\
\hline Coalition SH 1,4 & $4^{\text {th }}$ & $2^{\text {nd }}$ & $3^{\text {rd }}$ & $1^{\text {st }}$ & $5^{\text {th }}$ & $4^{\text {th }}$ & $2^{\text {nd }}$ & $1^{\text {st }}$ & $3^{\text {rd }}$ & $5^{\text {th }}$ & $3^{\text {rd }}$ & $4^{\text {th }}$ & $2^{\text {nd }}$ & $5^{\text {th }}$ & $1^{\text {st }}$ \\
\hline on SH 1,5 & $4^{\text {th }}$ & $2^{\text {nd }}$ & $3^{\text {rd }}$ & $1^{\text {st }}$ & $5^{\text {th }}$ & $4^{\text {th }}$ & $1^{\text {st }}$ & $2^{\text {nd }}$ & $3^{\text {rd }}$ & $5^{\text {th }}$ & $4^{\text {th }}$ & $3^{\text {rd }}$ & $2^{\text {nd }}$ & $5^{\text {th }}$ & $1^{\text {st }}$ \\
\hline Coalition SH 2.3 & $5^{\text {th }}$ & $3^{\text {rd }}$ & $4^{\text {th }}$ & $2^{\text {nd }}$ & $1^{\text {st }}$ & $2^{\text {nd }}$ & $5^{\text {th }}$ & $1^{\text {st }}$ & $3^{\text {rd }}$ & $4^{\text {th }}$ & $4^{\text {th }}$ & $3^{\text {rd }}$ & $4^{\text {th }}$ & $5^{\text {th }}$ & $2^{\text {nd }}$ \\
\hline Coc & $4^{\text {th }}$ & $2^{\text {nd }}$ & $3^{\text {rd }}$ & $1^{\text {st }}$ & $5^{\text {th }}$ & $5^{\text {th }}$ & $4^{\text {th }}$ & $1^{\text {st }}$ & $3^{\text {rd }}$ & $2^{\text {nd }}$ & $5^{\text {th }}$ & $3^{\text {rd }}$ & $4^{\text {th }}$ & $2^{\text {nd }}$ & $1^{\mathrm{st}}$ \\
\hline Coalit & $1^{\text {st }}$ & $3^{\text {rd }}$ & $4^{\text {th }}$ & $2^{\text {nd }}$ & $5^{\text {th }}$ & $5^{\text {th }}$ & $4^{\text {th }}$ & $1^{\text {st }}$ & $3^{\text {rd }}$ & $2^{\text {nd }}$ & $1^{\text {st }}$ & $5^{\text {th }}$ & $4^{\text {th }}$ & $3^{\text {rd }}$ & $2^{\text {nd }}$ \\
\hline Coali & $5^{\text {th }}$ & $3^{\text {rd }}$ & $2^{\text {nd }}$ & $1^{\text {st }}$ & $4^{\text {th }}$ & $5^{\text {th }}$ & $2^{\text {nd }}$ & $1^{\mathrm{st}}$ & $3^{\text {rd }}$ & $4^{\text {th }}$ & $5^{\text {th }}$ & $3^{\text {rd }}$ & $2^{\text {nd }}$ & $4^{\text {th }}$ & $1^{\text {st }}$ \\
\hline $\mathrm{Co}$ & $5^{\text {th }}$ & $4^{\text {th }}$ & $3^{\text {rd }}$ & $2^{\text {nd }}$ & $1^{\mathrm{st}}$ & $5^{\text {th }}$ & $4^{\text {th }}$ & $1^{\text {st }}$ & $3^{\text {rd }}$ & $2^{\text {nd }}$ & $5^{\text {th }}$ & $3^{\text {rd }}$ & $4^{\text {th }}$ & $2^{\text {nd }}$ & $1^{\text {st }}$ \\
\hline H 4 & $5^{\text {th }}$ & $4^{\text {th }}$ & $3^{\text {rd }}$ & $1^{\mathrm{st}}$ & $2^{\text {nd }}$ & $5^{\text {th }}$ & $4^{\text {th }}$ & $1^{\mathrm{st}}$ & $3^{\text {rd }}$ & $2^{\text {nd }}$ & $3^{\text {rd }}$ & $5^{\text {th }}$ & $4^{\text {th }}$ & $2^{\text {nd }}$ & $1^{\mathrm{st}}$ \\
\hline $\mathrm{Co}$ & $4^{\text {th }}$ & $5^{\text {th }}$ & $3^{\text {rd }}$ & $2^{\text {nd }}$ & $1^{\text {st }}$ & $4^{\text {th }}$ & $5^{\text {th }}$ & $1^{\text {st }}$ & $2^{\text {nd }}$ & $3^{\text {rd }}$ & $1^{\mathrm{st}}$ & $4^{\text {th }}$ & $5^{\text {th }}$ & $3^{\text {rd }}$ & $2^{\text {nd }}$ \\
\hline n SH $1,2,4$ & $3^{\text {rd }}$ & $5^{\text {th }}$ & $2^{\text {nd }}$ & $1^{\mathrm{st}}$ & $4^{\text {th }}$ & $4^{\text {th }}$ & $5^{\text {th }}$ & $1^{\text {st }}$ & $3^{\text {rd }}$ & $2^{\text {nd }}$ & $3^{\text {rd }}$ & $2^{\text {nd }}$ & $5^{\text {th }}$ & $4^{\text {th }}$ & $1^{\mathrm{st}}$ \\
\hline $\mathrm{Co}$ & $2^{\text {nd }}$ & $3^{\text {rd }}$ & $4^{\text {th }}$ & $1^{\mathrm{st}}$ & $5^{\text {th }}$ & $5^{\text {th }}$ & $1^{\text {st }}$ & $3^{\text {rd }}$ & $2^{\text {nd }}$ & $4^{\text {th }}$ & $3^{\text {rd }}$ & $3^{\text {rd }}$ & $1^{\text {st }}$ & $4^{\text {th }}$ & $2^{\text {nd }}$ \\
\hline Coa & $2^{\text {nd }}$ & $4^{\text {th }}$ & $3^{\text {rd }}$ & $1^{\text {st }}$ & $5^{\text {th }}$ & $4^{\text {th }}$ & $5^{\text {th }}$ & $1^{\text {st }}$ & $3^{\text {rd }}$ & $2^{\text {nd }}$ & $2^{\text {nd }}$ & $3^{\text {rd }}$ & $5^{\text {th }}$ & $4^{\text {th }}$ & $1^{\mathrm{st}}$ \\
\hline Coalition SH 1,3,5 & $4^{\text {th }}$ & $3^{\text {rd }}$ & $2^{\text {nd }}$ & $1^{\text {st }}$ & $5^{\text {th }}$ & $3^{\text {rd }}$ & $5^{\text {th }}$ & $1^{\text {st }}$ & $4^{\text {th }}$ & $2^{\text {nd }}$ & $4^{\text {th }}$ & $3^{\text {rd }}$ & $5^{\text {th }}$ & $2^{\text {nd }}$ & $1^{\text {st }}$ \\
\hline Coal & $4^{\text {th }}$ & $3^{\text {rd }}$ & $2^{\text {nd }}$ & $1^{\text {st }}$ & $5^{\text {th }}$ & $4^{\text {th }}$ & $5^{\text {th }}$ & $1^{\text {st }}$ & $3^{\text {rd }}$ & $2^{\text {nd }}$ & $4^{\text {th }}$ & $2^{\text {nd }}$ & $5^{\text {th }}$ & $3^{\text {rd }}$ & $1^{\text {st }}$ \\
\hline $\mathrm{Co}$ & $3^{\text {rd }}$ & $2^{\text {nd }}$ & $4^{\text {th }}$ & $1^{\text {st }}$ & $5^{\text {th }}$ & $4^{\text {th }}$ & $5^{\text {th }}$ & $1^{\text {st }}$ & $3^{\text {rd }}$ & $2^{\text {nd }}$ & $3^{\text {rd }}$ & $4^{\text {th }}$ & $5^{\text {th }}$ & $2^{\text {nd }}$ & $1^{\text {st }}$ \\
\hline n SH 2,3,5 & $5^{\text {th }}$ & $2^{\text {nd }}$ & $4^{\text {th }}$ & $1^{\text {st }}$ & $3^{\text {rd }}$ & $3^{\text {rd }}$ & $4^{\text {th }}$ & $1^{\text {st }}$ & $5^{\text {th }}$ & $2^{\text {nd }}$ & $3^{\text {rd }}$ & $4^{\text {th }}$ & $4^{\text {th }}$ & $2^{\text {nd }}$ & $1^{\text {st }}$ \\
\hline Coalition SH 2,4,5 & $4^{\text {th }}$ & $2^{\text {nd }}$ & $3^{\text {rd }}$ & $1^{\text {st }}$ & $5^{\text {th }}$ & $4^{\text {th }}$ & $5^{\text {th }}$ & $1^{\text {st }}$ & $2^{\text {nd }}$ & $3^{\text {rd }}$ & $4^{\text {th }}$ & $2^{\text {nd }}$ & $5^{\text {th }}$ & $3^{\text {rd }}$ & $1^{\text {st }}$ \\
\hline Coali & $4^{\text {th }}$ & $2^{\text {nd }}$ & $3^{\text {rd }}$ & $1^{\text {st }}$ & $5^{\text {th }}$ & $5^{\text {th }}$ & $4^{\text {th }}$ & $1^{\text {st }}$ & $2^{\text {nd }}$ & $3^{\text {rd }}$ & $1^{\mathrm{st}}$ & $5^{\text {th }}$ & $4^{\text {th }}$ & $3^{\text {rd }}$ & $3^{\text {rd }}$ \\
\hline $\mathrm{Co}$ & $4^{\text {th }}$ & $3^{\text {rd }}$ & $2^{\text {nd }}$ & $1^{\text {st }}$ & $5^{\text {th }}$ & $4^{\text {th }}$ & $2^{\text {nd }}$ & $1^{\text {st }}$ & $3^{\text {rd }}$ & $5^{\text {th }}$ & $4^{\text {th }}$ & $3^{\text {rd }}$ & $2^{\text {nd }}$ & $5^{\text {th }}$ & $1^{\text {st }}$ \\
\hline Coalition SH 1,2,3,5 & $4^{\text {th }}$ & $3^{\text {rd }}$ & $2^{\text {nd }}$ & $1^{\text {st }}$ & $5^{\text {th }}$ & $3^{\text {rd }}$ & $2^{\text {nd }}$ & $1^{\text {st }}$ & $4^{\text {th }}$ & $5^{\text {th }}$ & $3^{\text {rd }}$ & $5^{\text {th }}$ & $2^{\text {nd }}$ & $4^{\text {th }}$ & $1^{\mathrm{st}}$ \\
\hline Coalition SH 12.4.5 & $4^{\text {th }}$ & $2^{\text {nd }}$ & $3^{\text {rd }}$ & $1^{\mathrm{st}}$ & $5^{\text {th }}$ & $4^{\text {th }}$ & $1^{\text {st }}$ & $2^{\text {nd }}$ & $3^{\text {rd }}$ & $5^{\text {th }}$ & $4^{\text {th }}$ & $3^{\text {rd }}$ & $1^{\text {st }}$ & $5^{\text {th }}$ & $2^{\text {nd }}$ \\
\hline & $4^{\text {th }}$ & $2^{\text {nd }}$ & $3^{\text {rd }}$ & $1^{\text {st }}$ & $5^{\text {th }}$ & $2^{\text {nd }}$ & $5^{\text {th }}$ & $1^{\text {st }}$ & $3^{\text {rd }}$ & $4^{\text {th }}$ & $4^{\text {th }}$ & $3^{\text {rd }}$ & $5^{\text {th }}$ & $2^{\text {nd }}$ & $1^{\mathrm{st}}$ \\
\hline Coalition SH 2,3.4.5 & $5^{\text {th }}$ & $3^{\text {rd }}$ & $2^{\text {nd }}$ & $1^{\text {st }}$ & $4^{\text {th }}$ & $5^{\text {th }}$ & $4^{\text {th }}$ & $1^{\text {st }}$ & $3^{\text {rd }}$ & $2^{\text {nd }}$ & $5^{\text {th }}$ & $3^{\text {rd }}$ & $4^{\text {th }}$ & $2^{\text {nd }}$ & $1^{\text {st }}$ \\
\hline Grand Coalition & $3^{\text {rd }}$ & $2^{\text {nd }}$ & $4^{\text {th }}$ & $1^{\text {st }}$ & $5^{\text {th }}$ & $5^{\text {th }}$ & $2^{\text {nd }}$ & $1^{\text {st }}$ & $3^{\text {rd }}$ & $4^{\text {th }}$ & $3^{\text {rd }}$ & $5^{\text {th }}$ & $2^{\text {nd }}$ & $4^{\text {th }}$ & $1^{\text {st }}$ \\
\hline Result & $3^{\text {rd }}$ & - & - & $1^{\text {st }}$ & $2^{\text {nd }}$ & $3^{\text {rd }}$ & $2^{\text {nd }}$ & $1^{\text {st }}$ & - & - & - & $3^{\text {rd }}$ & $2^{\text {nd }}$ & - & $1^{\text {st }}$ \\
\hline
\end{tabular}

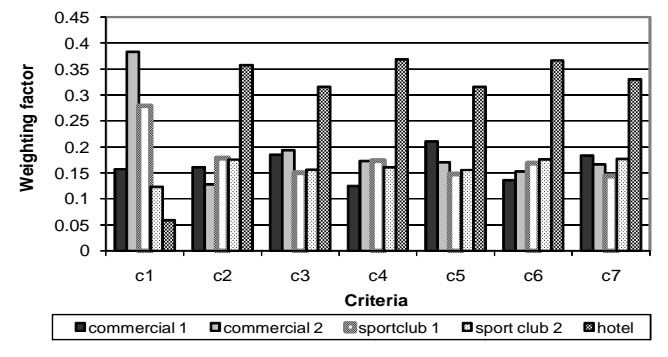

Fig. 3. Weighting factor of each criterion for each alternative (Architect's)

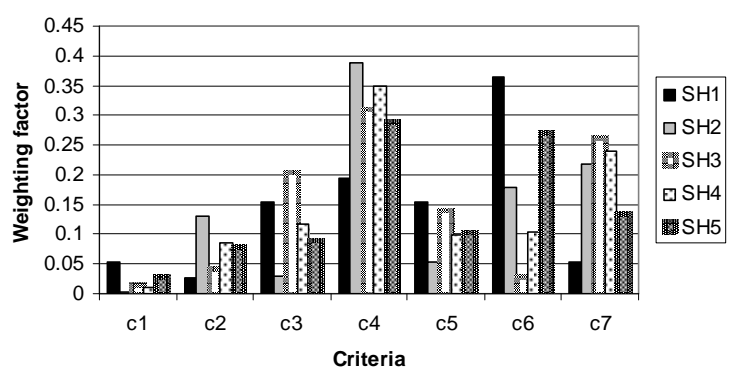

Fig. 4. Weighting of preferences for each stakeholder



Fig. 5. Weighting factor of every alternative for each criterion

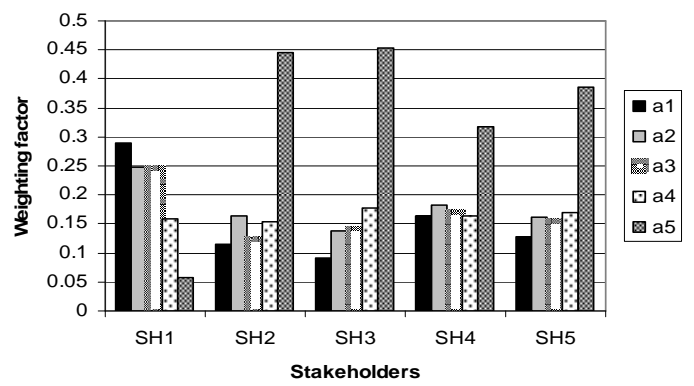

Fig. 6. Weighting factor of every alternative for each decision maker (SH1-SH5) 
All decision makers work in a fair and stable way so that they are motivated to stay with the coalition structure rather than move out it. Negotiation could be considered as a process of distributed rational decision making [6]. The greater the number of person involved in the hierarchy construction, the greater is the range of ideas. The enumeration of alternatives and the development of decision hierarchy help the group to debate the problem. The judgments remain subjective. Wanyama and Far [7] wrote that sets of activities could move, expand and, retract during negotiation. By adapted model of coalition formation from [22] and [42], the model works in the context of multi-criteria group decision making. Each person evaluates the available solution option individually based on the preference model using an AHP model. Thereafter, they select the solutions with the highest score as the offers to their negotiation opponents. At the end of every negotiation round, each person adjusts its preference value function in a way so to increase the utility associated with the solution that the agent regards to be the "best-fit" for its coalition.

\section{CONCLUSION}

The proposed model for multi person decision on unfinished construction project can help decision makers to evaluate and rank the solution alternatives to each decision. Results (optimization based goal programming, and negotiation based coalition formation) are expected. Both analyze are going concern where optimization not only consider function of overall cost but also consider preference weight of each project to each decision as the preference value of each decision maker. Follow up research is particularly required, primarily in the study of an agent-based negotiation on multi criteria group decision. Future research in the application of this methodology in many field of decision will build a wide range of knowledge to solve the theoretical and practical gap in multi person decision and negotiation in construction project.

\section{REFERENCES}

[1] C. M. Tam, T. K. L Tong, H. Zhang, 2007, Decision Making and Operations Research Techniques for Construction Management. City University of Hong Kong, Hong Kong.

[2] M. J. Scott, 1999, "Formalizing negotiation in engineering design", Ph.D. Dissertation, California Institute of Technology Pasadena.

[3] X. Zhang, 2002, "Sophisticated negotiation in multi-agent systems", Ph.D. Dissertation, University of Massachusetts Amherst.

[4] S. Kraus, J. Wilkenfeld, G. Slotkin, 1995, "Multi-agent negotiation under time constrains". Artificial Intelligence, Vol. 75, pp. 297-345.
[5] X. Wang, 2006, "A fuzzy logic based intelligent negotiation agent", Master Thesis, School of Information Technology and Engineering University of Ottawa, Canada.

[6] M. Morge, P. Beaune, 2004, "A negotiation support system based on multi-agent system: specify and preference relation on arguments", ACM Symposium on Applied Computing.

[7] T. Wanyamaand B. H. Far, 2007, "A protocol for multi-agent negotiation in a group-choice decision-making". Journal of Network and Computer Applications, Vol. 30, pp. 11731195.

[8] J. D. McKeen, T. Guimaraesand, J. C. Wetherbe, 1994, "A comparative analysis of MIS project selection mechanisms". ACM SIGMIS Database, Vol. 25, No. 1, pp. 43-59.

[9] F. Krawiec, 1984, "Evaluating and selecting research project by scoring", Research Management, Vol. 27, No. 2, pp. 2123.

[10] B. V. Dean, M. J. Schniederjans, 1991, “A multiple objective selection methodology for strategic industry selection analysis", IEEE Transaction on Engineering Management, Vol. 38, No. 1, pp. 53-62.

[11] J. W. Lee, Kim, S. H., 2000, "Using analytic network process and goal programming for interdependent information system project selection", Computer and Operation Research, Vol. 27, pp. 367-382.

[12] C. J. Anumba, O.O. Ugwu, L. Newnham, A. Thorpe, 2002, "Collaborative design of structures using intelligent agents", Automation in Construction, Vol. 11, pp. 89-103.

[13] Z. Ren C., J. Anumbaand, O. O. Ugwu, 2003, "The development of a multi-agent system for construction claims negotiation". Advances in Engineering Software, Vol. 34, pp. 683-696.

[14] R. J. Dzengand Y.C. Lin, 2004, "Intelligent agents for supporting construction procurement negotiation", Expert System with Applications, Vol. 27, No. 1, pp. 107-119.

[15] S. K. Kimand, J.S. Russell, 2003, "Framework for an intelligent earthwork system-Part I. System architecture", Automation in Construction, Vol. 12, No. 1, pp. 1-13.

[16] K. Kim, B.C. Paulson, 2003, "Multi-agent distributed coordination of project schedule changes", Computer-Aided Civil and Infrastructure Engineering, Vol. 18, No. 6, pp. 412-425.

[17] J. Yan, T. Kuphaland, J. Bode, 2000, "Application of multiagent system in project management", International Journal Production Economics, Vol. 68, pp. 185-197.

[18] N.K. Nassar, 2005, "An integrated framework for evaluation, forecasting and optimization of performance of construction projects", Ph.D. Dissertation, University of Alberta.

[19] T. Kedro, 1994, "A distributed problem solving approach to collaborative facility engineering through agent based software integration”, Ph.D. dissertation, Stanford University.

[20] M. M. R. Halfawy, 1998, "A multi agent collaborative framework for concurrent design of constructed facilities", Dissertation, the Ohio State University.

[21] T. L. Saaty, 1994, The Fundamentals of Decision Making and Priority Theory with the Analytic Hierarchy Process, Vol. 4 Of AHP Series, RWS Publications, Pittsburg.

[22] T. Wanyama, 2006, "Decision support for cots selection", Ph.D Dissertation, University of Calgary.

[23] J. Wang and S. Zionts, 2008, "Negotiating wisely, considerations based on MCDM/MAUT", European Journal of Operation Research, Vol. 188, pp. 191-205.

[24] A. Kelly, 2003, Decision Making using Game Theory: an Introduction for Manager, Cambridge University Press, United Kingdom.

[25] D. K. H. Chua, 1999, "Critical Success factors for different project objectives", Journal Constructions Engineering and Management, Vol. 125, No.3, pp. 142-150.

[26] J. R. Meredith, S. J. Mantel, J. Wiley, Sons, 2003, "Project management: A managerial approach", Vol. 5, pp. 621-628. New York. 
IPTEK, The Journal for Technology and Science, Vol. 21, No. 2, May 2010

[27] H. Kerzner, J. Wiley, Sons, 2009, "Project management: a system approach to planning, scheduling, and controlling", Vol. 10, Hoboken, NJ.

[28] D. I. Cleland, R. L. Ireland, and McGraw Hill, 2006, "Project management: strategic design and implementation", Vol. 5, pp. 304-317, New York.

[29] F. Ghasemzadeh, 1999, "A zero one model for project portfolio selection and scheduling". Journal of the Operational Research Society, Vol. 50. No. 7, pp. 745-755.

[30] A.B. Badiruand, P.S. Pulat, 1995, "Comprehensive Project Management: Integrating Optimization Models. Management Principles and Computers", Prentice Hall, New Jersey, pp. 210-272.

[31] K. R. Molenaar and A.D. Songer, 1998, "Model for public sector design-build project selection", Journal Constructions Engineering and Management, Vol. 124, No. 6, pp. 467-479.

[32] P.K. Dey., 2006, "Integrated project evaluation and selection using multi attribute decision making technique", International Journal Production Economics, Vol. 103, pp. 90-103.

[33] E. Triantaphyllou, 2000, Multi Criteria Decision Making Methods : A Comparative Study, Kluwer Academic Publisher, Dordrecht the Netherlands.

[34] D.F Jones and M. Tamiz, 2010, "Practical Goal Programming", Springer Books.
[35] K. Peniwati, 2007, "Criteria for evaluating group decision making methods", Mathematical and Computer Modelling, Vol. 46, pp. 935-947.

[36] N. E. Zarourand, S. Bouzidi, 2006, "Coalition formation for cooperative information agent-based system", International Journal of Computers, Communications and Control, Vol. 1, No. 3, pp. 85-92.

[37] C. March, 2009, "Operations management for construction", Taylor and Francis Group, London.

[38] G. Shen, P. Brandon, A. Baldwin, 2009, "Collaborative construction information management", Taylor and Francis Group, London.

[39] J. Von Neuman and O. Morgenstern, 1947, "Theory of games and economic behavior, Vol. 2, Princeton University Press Princeton, NJ

[40] E. N. Barron, 2008, "Game theory an introduction", WileyInter Science-John Wiley and Sons. Hoboken, NJ.

[41] S. Kraus, 2001, "Strategic negotiation in multi-agent environment", MIT Press, Massachusetts.

[42] T. Wanyama, B.H. Far, 2006, "Negotiation coalitions in group-choice multi-agent systems", AAMAS'06, pp. 408-410. 